\title{
ЕЛЕКТРОННІ ІНФОРМАЦІЙНІ СИСТЕМИ В МЕДИЦИНІ ТА БІОЛОГІЇ: ЗАГАЛЬНИЙ АНАЛІЗ
}

О. М. Ключко

\author{
Національний авіаційний університет
}

\begin{abstract}
У публікації узагальнено та проаналізовано досвід застосування електронних інорормаційних систем із використанням баз даних. Коротко проаналізовано розвиток ідеї інорормаційних систем та досліджено їх зразки, розроблені для медицини та біології, що описано у численних науково-технічних публікаціях (близько 370). Виконана класифрікація таких систем, що традиційно були розроблені для медицини та біології. Далі розглянуто різні приклади таких інорормаційних систем, а також систем, що мають характеристики як медичних, так і біологічних, щоб полегшити розроблення майбутніх досконаліших версій.

Продемонстровано, що можна виділити кілька основних типів інформаційних систем із базами даних для медицини, біології. Виконуючи їх класифрікацію, нами впорядковано такі системи відповідно до кількості публікацій, присвячених кожному типу.

За результатами дослідження зроблено ряд висновків: 1. Медичні інформаційні системи характеризуються найбільшою чисельністю, різноманітністю та наближеністю до практики. 2. Електронні інформаційні системи в нейрофрізіології, біології характеризуються більшою наближеністю до наукових досліджень. 3. Основна увага розробників зосереджена зараз на розробленні: медичних інформаційних систем загального призначення, електронних бібліотечних систем, електронних систем для роботи з документами, експертних систем і телекомунікаційних систем, що з'явилися в цих списках останнім часом, з початку пандемії SARS-CoV-2 (2019-nCoV). Інші типи були представлені менше, ніж зазначені.
\end{abstract}

Ключові слова: інформатика, інформаційна система, бази даних.

\section{ELECTRONIC INFORMATION SYSTEMS IN MEDICINE AND BIOLOGY: GENERAL ANALYSIS}

\author{
O. M. Klyuchko
}

\section{National Aviation University}

Background. In present publication we generalized and analyzed the experience of electronic information systems with databases use in medicine and biology, as well as classified observed versions of modern medical and biological information systems for the use of this knowledge for the construction of new information systems.

Materials and methods. Methods of comparative theoretical analysis were applied for the results searched in databases of Springer, Academic Press as well as Google Scholar, PubMed, Medine. The studies were done to observe, generalize and analyze the examples of highly developed technical information systems with databases elaborated for medicine and biology.

Results. We analyzed briefly the development of ISs idea, examined ISs for medicine, biology from numerous scientific and technical publications (approximately 370). Then we classified such systems, which traditionally refer to both biological and medical sciences. Further we observed different examples of such information systems, as well as systems that have characteristics both medical and biological in order to facilitate the invention of future more advanced their versions.

We have demonstrated that several basic types of ISs with databases for medicine, biology can be subdivided. Classifying, we have ordered them according to the number of publications devoted to each type.

Conclusion. Following conclusions were done: 1 . Medical information systems are characterized by the greatest quantity, diversity and proximity to the practice. 2. Electronic information systems in neurophysiology and biology are characterized by the greater proximity to scientific research. 3. The main focus of the developers is focused now on the development of: medical information systems of general purposes, electronic library systems, electronic systems for work with documents, expert systems, and telecommunicate systems appeared in these lists recently, since the beginning of SARS-CoV-2 (2019$\mathrm{nCoV}$ ) pandemic. Other types were represented less than above mentioned ones.

Key words: computer science, information system, databases. 


\title{
ЭЛЕКТРОННЫЕ ИНФОРМАЦИОННЫЕ СИСТЕМЫ В МЕДИЦИНЕ И БИОЛОГИИ: ОБЩИЙ АНАЛИЗ
}

Е. М. Ключко

\author{
Национальный авиационный университет
}

\begin{abstract}
В публикации обобщен и проанализирован опыт применения электронных информационных систем с использованием баз данных. Кратко проанализировано развитие идеи инорормационных систем и исследованы их образцы, разработанные для медицины и биологии, описанные в многочисленных научно-технических публикациях (около 370). Выполнена классифрикация таких систем, которые традиционно были разработаны для медицины и биологии. Далее рассмотрены различные примеры таких инорормационных систем, а также систем, имеющих характеристики как медицинских, так и биологических, чтобы облегчить разработку будущих более совершенных их версий.

Продемонстрировано, что можно выделить несколько основных типов инорормационных систем с базами данных для медицины, биологии. Выполняя их классификацию, упорядочивали в соответствии с количеством публикаций, посвященных каждому типу.

По результатам исследования сделано ряд выводов: 1. Медицинские инорормационные системы характеризуются наибольшей численностью, разнообразием и приближенностью к практике. 2. Электронные информационные системы в нейрофизиологии, биологии характеризуются большей приближенностью к научным исследованиям. 3. Основное внимание разработчиков сосредоточено сейчас на разработке: медицинских информационных систем общего назначения, электронных библиотечных систем, электронных систем для работы с документами, экспертных систем и телекоммуникационных систем, появившихся в этих списках в последнее время, с начала пандемии SARS-CoV-2 (2019-nCoV). Другие типы были представлены меньше, чем указанные.
\end{abstract}

Ключевые слова: информатика, информационная система, базы данных. 
Introduction. The progress in medicine and biology in contemporary world is unprecedented. This happens not only due to the crucial necessity of public health protection in contemporary epidemiological situation of coronavirus SARS-CoV-2 (2019-nCoV) infection spreading. This happen also due to continuous achievements in areas of molecular and genome studying and modeling, achievements in disease characteristics studies in the clinical aspect of health care, discoveries in the field of pharmacology, and, on other hand, due to the intensive development of information technologies (IT) and computer technologies (CT), mainly on the basis of the databases (DBs), which gave the opportunity to work with great volumes of obtained digitized results [1, 2].

The notion «information system» (IS) means any system, that is capable to receive, to process, to memorize, and to transmit the information according to classic definition [2]. In our studies, like other authors, we distinguished two types of information systems (ISs) [2]. So, «information system» may mean: 1 - living systems in nature, we suggest to call them «nIS» (natural information systems), and 2 - technical information systems, respectively «tIS» (technical information systems), namely this publication is dedicated to the observation of the latter ones. During the last decade the «hybrid» ISs have been developed also; they unite characteristics of nIS and tIS [1]. Present review about the elaboration of modern electronic information systems (ISs) on the basis of databases (DBs) for biotechnology (and biology in general), we have done after the analysis of more than 370 contemporary sources (since 2000 year), as well as number of earlier works; in general, relevant publications have been reviewed over the past 35-30 years [7-18]. Some authors' works with the description of tISs for medicine and biology are in [2-6], some of such works were protected by patents $[17,18]$. On the base of searched data and analysis of ISs diversity our original classification of ISs was developed; and such classification schemes are presented in this article. Three classification schemes were presented: medical ISs, ISs for biology and, for comparison, ISs for neurophysiology. We have demonstrated that there are several basic types of ISs with DBs for medicine and biology. At the end of present article some of ISs for medicine and biology we have characterized briefly.

It should be noted that scientific and technical publications about novel tISs (technical information systems) often contain a number of deficiencies. Most of them announced only the development of any tIS and give it superficial characteristic which should announce a novelty. But they omitted numerous technical characteristics of the systems, the principles of their functioning, and etc.; all these complicate the analytical research. Despite of this, we have analyzed the experience of modern ISs constructing, which can be applied for successful works in biotechnology. Today all such tISs are network-based with DBs [2-9].

Purpose of the work: to study and to analyze a number of contemporary examples of technical information systems with databases elaborated for medicine and biology, as well as to classify observed versions of modern medical and biological information systems with further detailed description of some versions for the use of these knowledge for the construction of new systems.

Materials and methods of investigations. Methods of comparative theoretical analysis were applied for the results searched in databases of Springer, Academic Press as well as Google Scholar, PubMed, Medine. The studies were done to observe, generalize and analyze the examples of highly developed technical information systems with databases elaborated for medicine and biology.

Results and their discussion. Place of information computer technologies for medicine and biology among other computer disciplines. Information computer technologies (ICT) have been developing so rapidly in recent years, that new methods, developments, ideas in computer sciences appear almost daily. At the same time, the volume of up-to-date information in various computer industries and, consequently, the number of courses taught to students of computer sciences are increasing rapidly. Usually, the latest developments attract the most attention, so the average of students sometimes have the feeling that some computer sciences which aroused the imagination of their peers 15 years ago are already outdated. Teachers' arguments that «the latest developments are based on those that have become classic, so the classics should be studied first,» often have no success. Therefore, in order to reconcile the experience and investigative mind, let's try to show own understanding of the correlation between different branches in computer disciplines on fig. 1.

At the center of this scheme is «Mathematical Modeling», an extremely important compartment of methods and knowledge in computer science that can be rightfully considered as classic one. Indeed, it could be said that mathematical modeling was at the 
forefront of computer technology until the early 1990s. The original data, models, methods, etc. produced by this compartment find their application in the practice, which is presented on the figure as compartment «Technical means». A variety of mechanisms or devices, such as robots, expert systems, automated devices, and other computer-controlled systems, could be such practical applications. Initially, at a historical stage we called «Stage 1», the created models might not need much input data, and sometimes they could even be placed on a simple A4-sized tag. But the amount of data that needed processing was increasing rapidly, and at the «Stage 2», the input data were organized into the simple databases (DBs) as it was shown on the figure. For example, such DBs might be done using the first versions of DBase or FoxPro.

Due to technological progress, increasing the power and speed of computers, mankind transition to personal computers (PCs) and the creation of networks, the prerequisites appeared that the databases became increasingly important («Stage $3 »)$. Systems for databases’ management have been so refined and developed that many preparatory operations with the data became possible to perform even before the data were received in the compartment «Mathematical modeling». And the next step was the level of such development of input data management that appeared as a result of this «Information Technologies» with included databases made it possible to separate into specific compartment (shown on the figure for the «Stage $3 »$ ). ISs with databases in biology and medicine are the subsets of the «Information Technologies» and the «DB» of the Stage 3 (not shown on the figure).

Thus, it can be stated that at the modern level of computer technology development, different types of methods coexist successfully: both the older in time of creation and the newest methods, technologies and developments. Their importance and role in the modern world is determined not by the time of creation, but by how much they are needed in practical activity of human. For example, you can refer to the practice of large USA banks, which have both the latest powerful PC models and older and cheaper, if they can successfully perform the necessary simple operations. Broad enough spectrums of ICT co-exist successfully if they meet the needs of such companies.

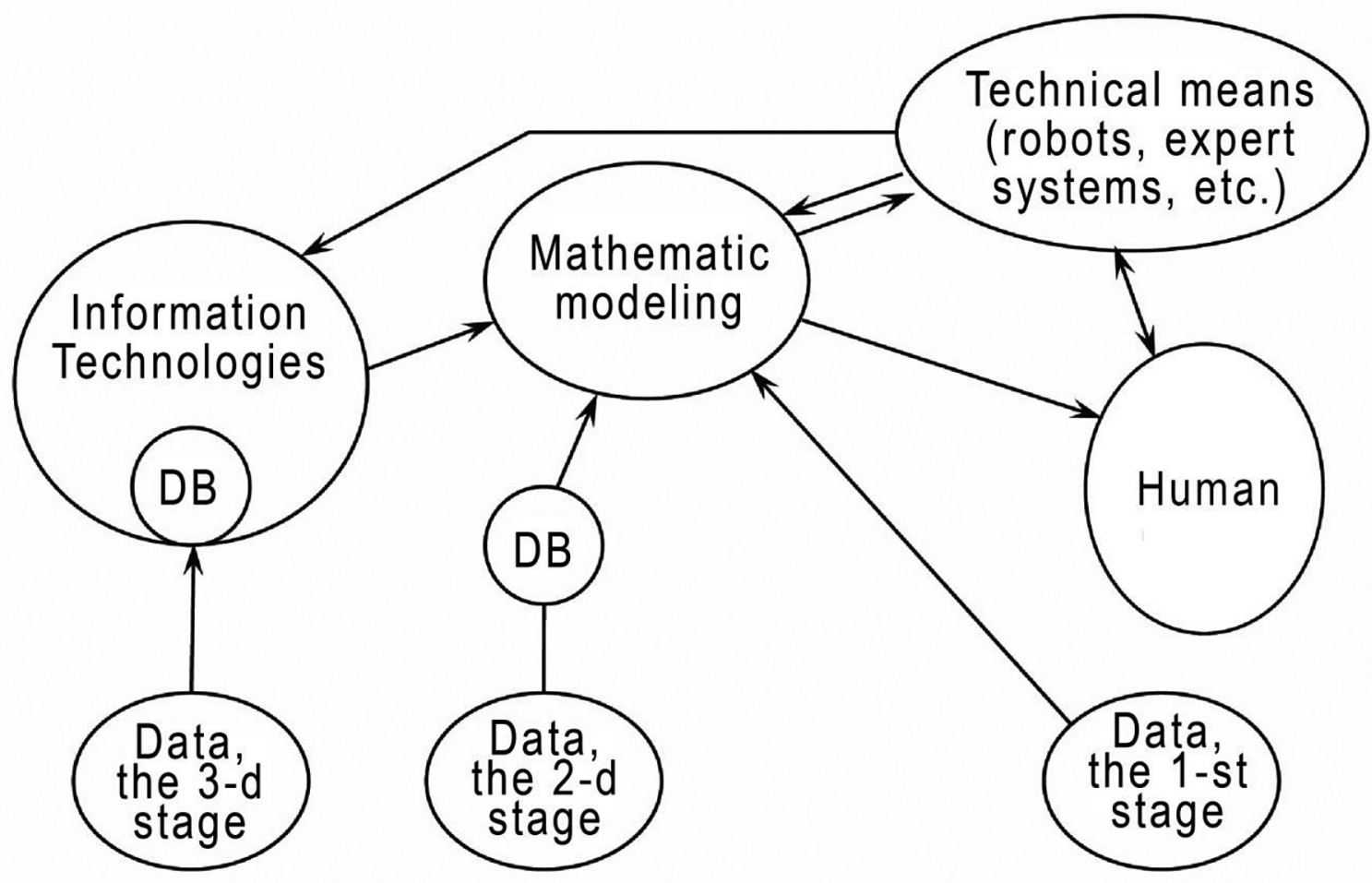

Fig. 1. Contemporary ISs with DBs in general pattern of computer knowledge and technologies (explanation see in text)

Importance of IT development for medicine and biology. The importance of IT developments for all biological branches has often been highlighted during contemporary international forums with the participation of physicians, biologists, managers and IT professionals. One of the first important forums - VLDB 2000 Conference - had happened on June, 2000. VLDB 2000 was dedicated to the prediction of the ways of 
IT development for the biology and medicine; for the control of situation with biodiversity and ecosystems $[2,10]$. It was noted that the study of biodiversity and ecosystems refers to those sciences that can (and must be) fully formalized and informative, despite the fact that the objects of their study are extremely complex. The new branch «Informatics in Biodiversity and Ecosystems» (BDEI - BREI) was officially started at this meeting [10]. It was emphasized that the diversity of living organisms in nature is an impressive feature of our reality. As a result of biodiversity existence, the people of the Earth were provided with clean air and water, food, homes, medicine, and etc. Finally, the biodiversity based on the existence of ecosystems gives billion dollars to national economies of different countries, either directly, through the agriculture, forestry, fishing, or as a result of protecting crops, pest control practices, soil restoration, carbon dioxide removal, nitrogen fixation, environment perfection. Obviously, this was one of the most important areas of vital importance; and it is important in terms of science, education, economics and government control. Therefore, the development of electronic ISs, which would enable to realize the scientific study of the nature at the modern level, educational work and rational economic development of nature with the support of governments, was one of the most important tasks of that time [10]. It was emphasized that for 2000-th year humanity has not had yet sufficiently good IT/CT tools for the solution of such problems. Therefore, it was necessary to invent a new generation of such means, including means of satellite environmental control and computer processing of obtained biological information. At the same time it was necessary to solve the problem of matching and ordering into the linked DBs the entire volume of biological data of various natures, both obtained by digital and classical means during the centuries. This task was extremely complicated, since in electronic databases in ISs should be ordered the latest digitized data at the level of molecular biology, genetics, biochemistry with its processes and reactions, as well as the data from field observations of species, observations of changes in the environment, data of classical taxonomy (and they should correlate with each other!) At the same time, these data should be in such form, that they can be processed, analyzed and compared jointly [10]. One such IT/CT tool for this period was called the «Super Blue Gene», it was the supercomputer which IBM started to develop on 2000 for the analysis of thousands of protein molecules composition of various species living on the Earth [2].
Classification of technical information systems with databases in medicine. Let's observe the examples of various modern ISs with DBs in medicine (and further in biology), information about which was published since 2000. In our list there are contemporary electronic databases with access to the Internet with information in medicine, designed during the last 25 years. Studying all found descriptions of tIS elaborated for medicine (patents, articles, books, etc.) we had revealed some regularities. Despite the diversity of such systems (and, accordingly, despite the diversity of publications), it was possible to distinguish certain well-defined types of ISs among them. It should be noted that such classification in the finished form in the scientific and technical literature until 2008 did not exist; it is original and the author made it on the basis of materials of about 370 publications. We have demonstrated that there are several basic types of ISs with DBs elaborated for medicine. This allowed us to develop original classification of ISs basing on the analysis of hundreds of contemporary publications and it is suggested your attention. Present chapter is devoted to analysis of the diversity of medical ISs and their classification. In following chapters the same results are presented for ISs in biology, and further, for comparison, for ISs in neurophysiology. We offer the results of our suggested classification of modern ISs for the facilitation of future ISs' versions construction.

It is necessary to mention that according to our studying, the intensive development of ISs in medicine started earlier (approximately 24-27 years ago) than in biology (17-18 years ago) [2]. Moreover, medical ISs demonstrate more variable forms, versions and types (fig. 2) in comparison with biological ones. It seems that large variety of tISs' versions in modern medicine is due to a good funding of the works related to medicine and health protection in the world. Thus, among the ISs with DBs for medicine one can distinguish (fig. 2): medical ISs of general purposes, expert systems, electronic systems for working with images, electronic systems for working with medical documents, systems for scientific purposes, library medical systems, electronic educational systems in medicine, electronic medical databases.

To the first positions in this list we placed the systems, information about which was published in the most numerous contemporary scientific and technical sources. For example, the group «Medical ISs of general purposes» included large and complex medical ISs developed for hospitals, medical research centers, etc. They united large numbers of sectors, 
DBs, electronic libraries and other services, sometimes complex networks with information defense and etc. The developers paid great attention to them, respectively, because of health care and health protection purposes. Such ISs were of the greatest demand of users, often embodied in practice in modern hospitals, laboratories and etc. So, these ISs felt into our section «Medical ISs of general purpose». This can be explained by the practical needs of clinical medicine, which requires the most of such versions.

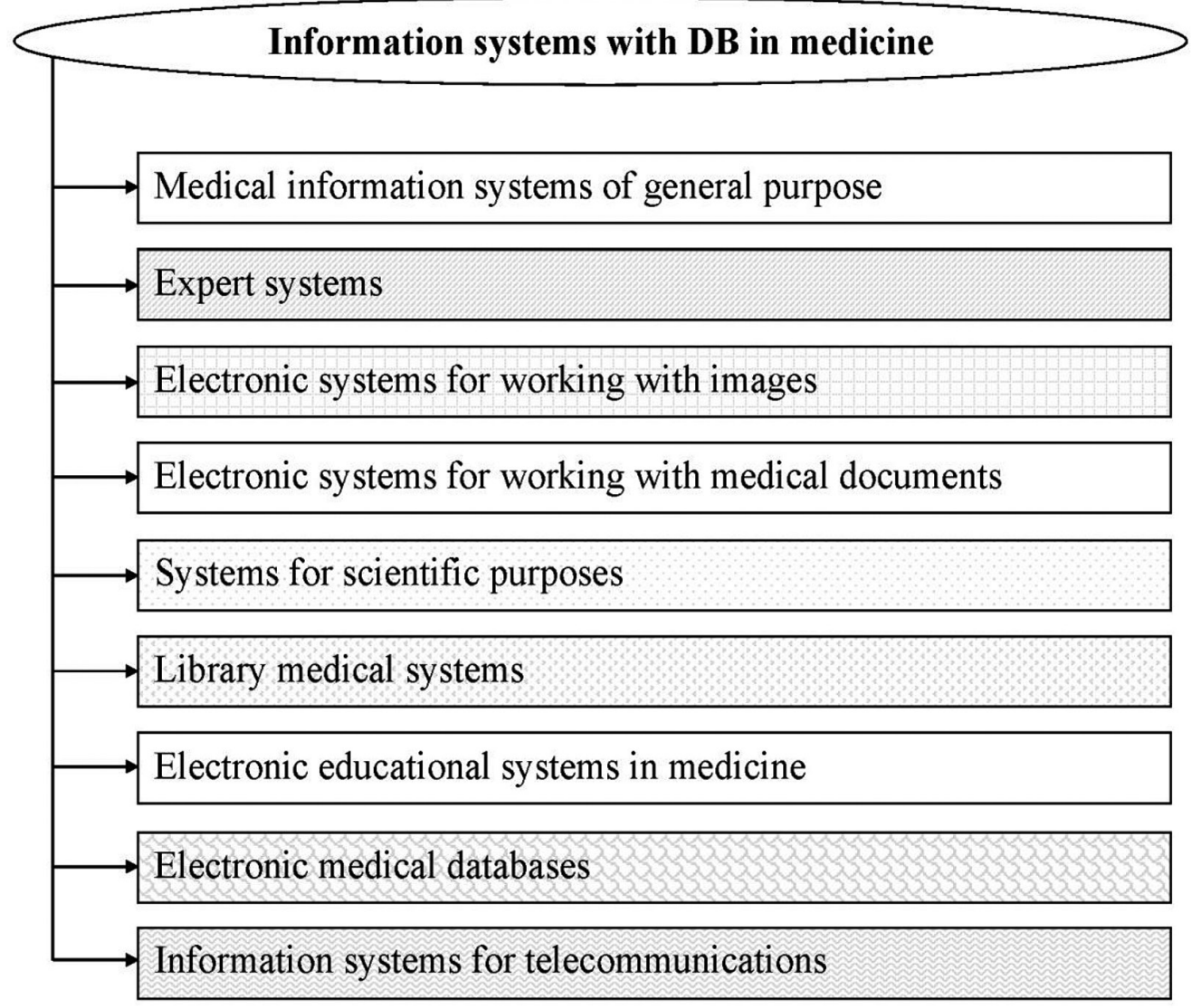

Fig. 2. Variety and classification of information systems with databases for medicine

When viewed the list of ISs classification from the top to the end, the number of publications corresponding to one specified type of the system decreases, and in the section «Electronic medical databases» felt to the lowest number of publications. This does not mean that electronic medical DBs were not important in medical practice. Such pattern could also be explained by the fact that the procedure for creating of such databases is standard, described in university textbooks, and perhaps the developers of such DBs did not see them as novelty, required for scientific publications.

«Information systems for telecommunications» occupied the lower position in our scheme (fig. 2). We have inserted this type of ISs recently, through few months after the beginning of pandemic caused by coronavirus SARS-CoV-2 (2019-nCoV). Because of necessity of adaptation in this situation, millions of people in whole world have to isolate themselves with continuation of their work (or to occupy themselves using ICT). This situation stimulated intensive progress in telecommunicate ISs, their number had increasing dramatically — respectively, they appeared in our list. Sure, telecommunicate technologies were 12-15 years ago too, but such ISs were not so numerous and diverse as today. Present days during the pandemic really became the «high point» for telecommunicate technologies.

Classification of information systems with databases in biology. For the construction of tIS for biology we suggested to study the experience of medical tIS elaboration because of the following reasons. 1 Medicine is one of the nearest spheres for biology that demonstrates the great variety and quality of IS because of good finding (people take care about their health ever). 2 - For biologists (as well as other professionals) there were not important from what IS 
to get the data for their work, if only this data were. Indeed, for the research work the real scientific data are necessary, independently on the source of their origin (in medical tIS there are lots of necessary data). 3 - Therefore, for the construction of similar tISs for biology, one needs to know the prototypes from medical tISs to develop the better ones, similar and even more suitable systems. 4 - In our originally constructed tIS, mentioned article, a biochemical electronic laboratory is added. According to this example, one can add to tIS all necessary segments: for biology, and other ones. 5 - Biological applications in medicine are very important. 6 - Finally, it is very useful for engineers in biology to know the different types of medical tISs as prototypes for the success of their work. To give to professionals the possibilities to invent new IS versions more effectively, we decided to observe some tIS prototypes in medicine and biology.

Describing the classification of electronic ISs in biological sciences we analyzed them in the same manner as medical ones (see above). Placing these ISs types in hierarchy (fig. 3), we followed the same principle as above: the more publications contain modern scientific and technical sources about this type of systems; respectively, the higher its name was in our list. Similar types of systems in biology and medicine we marked with the same hatch (for example, «Electronic systems for working with images» are marked by a square hatch for all branches; fig. 2, 3). Regarding to the classification of ISs in biology, most of them were scientific ISs with DBs according to their purposes and the developers paid the main attention to them. Such situation looked like similar to «Medical ISs of general purpose» from fig. 2. At the same time, such scientific systems in biology also performed educational functions, so, they are (and may be called) «Educational ISs». Further, according to the attention of developers, and consequently, according to the number of developed systems were electronic libraries in biology and biological databases. There were relatively not numerous publications about the systems designed for the work with images. Abovementioned could not be applied to systems for the work with images in anatomy, cytology — such systems were numerous, quite thoroughly developed, because they support some medical operations (for example, surgeons) and computer diagnostics are based on them also. But in our classification, they were at the third position from the top in the classification of ISs for medicine, because they are necessary for the needs of this sphere; so, they were first developed and applied with equal intensity in medicine and in biology.

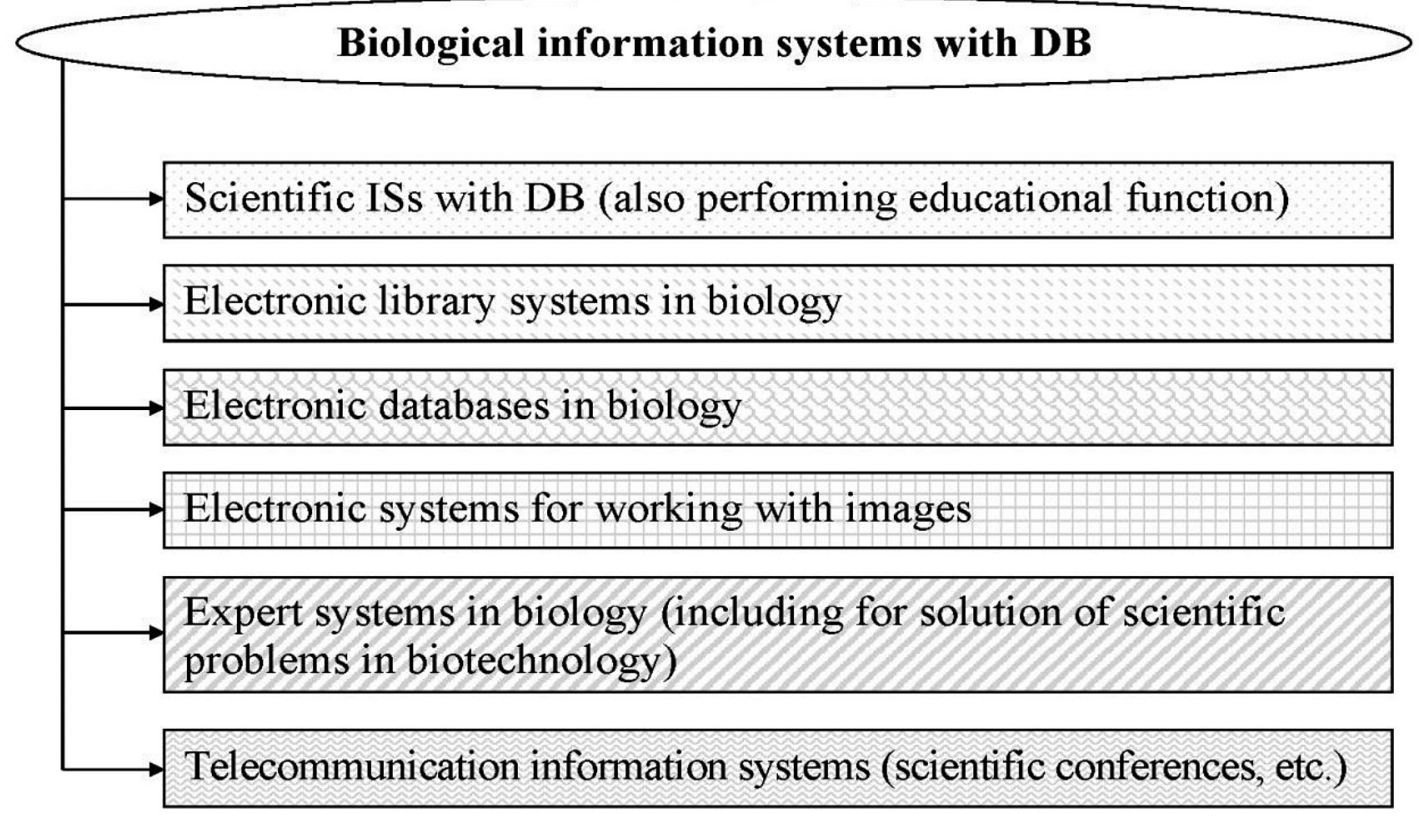

Fig. 3. Biological information systems with databases

Computer expert biological systems were the most close to the biological practice, for example, for the estimation of pests' presence on fields, for bee diseases identification, and etc. Thus, the classification of ISs for biology could be presented as: scientific ISs with DBs (also performing educational function), electronic library systems in biology, electronic databases in biology, electronic systems for the work with images, 
expert systems in bio-logy (including ones for solution of scientific problems in biology) (fig. 3).

In comparison with our previous publications [2], we added to our scheme «Telecommunication information systems» for biology at the last position too. During today pandemic caused by SARS-CoV-2 (2019-nCoV), these ISs for biology are in progress too. Their difference from the same for medicine is in more «academic» direction of their functions and use (scientific conferences, etc); medical ISs are linked more with the practice.

Types of information systems used by professionals both in medicine and biology. As an example of such systems we can observe a neurophysiology; moreover, many professionals in both medicine and biology are interested in the data obtained in this sphere. Neurophysiologic data are used by professionals both medical and biological sciences. So, some peculiarities of ISs' classification in neurophysiology were similar to both biology and medicine (let's compare figures 2, 3, 4) [2]. Sure, it did not have «Medical ISs of general purpose» group because there is no need in their development — such tasks are important for medical practice only. However, the neurophysiology deals with the solution of purely scientific problems, so developed electronic systems here have to facilitate their solution. There are also the need to develop own large databases and electronic library systems to store numerous experimental neurophysiological results and data from literary sources. So, in the classification list for neurophysiology, some items would coincide with the list for medical ISs, and some - with biological ISs. As a result, the general classification for the field of neurophysiology acquired the following form (fig. 4): expert systems in neurophysiology (including ones for the solution of scientific problems), electronic systems for the work with images, electronic library systems in neurophysiology, and electronic databases in neurophysiology [2].

We could forecast that classification list of ISs types for neurophysiology will demonstrate similar regularities as ones for neurophysiology, because this sphere is also at «intersection» between biology and medicine; but final correct conclusions we will be able to make after the upcoming additional studies. Telecommunication ISs present at the lowest stage of this scheme too because of explained above reasons. Sure, they are used mainly for academic purposes as well (scientific communication, conferences etc.)

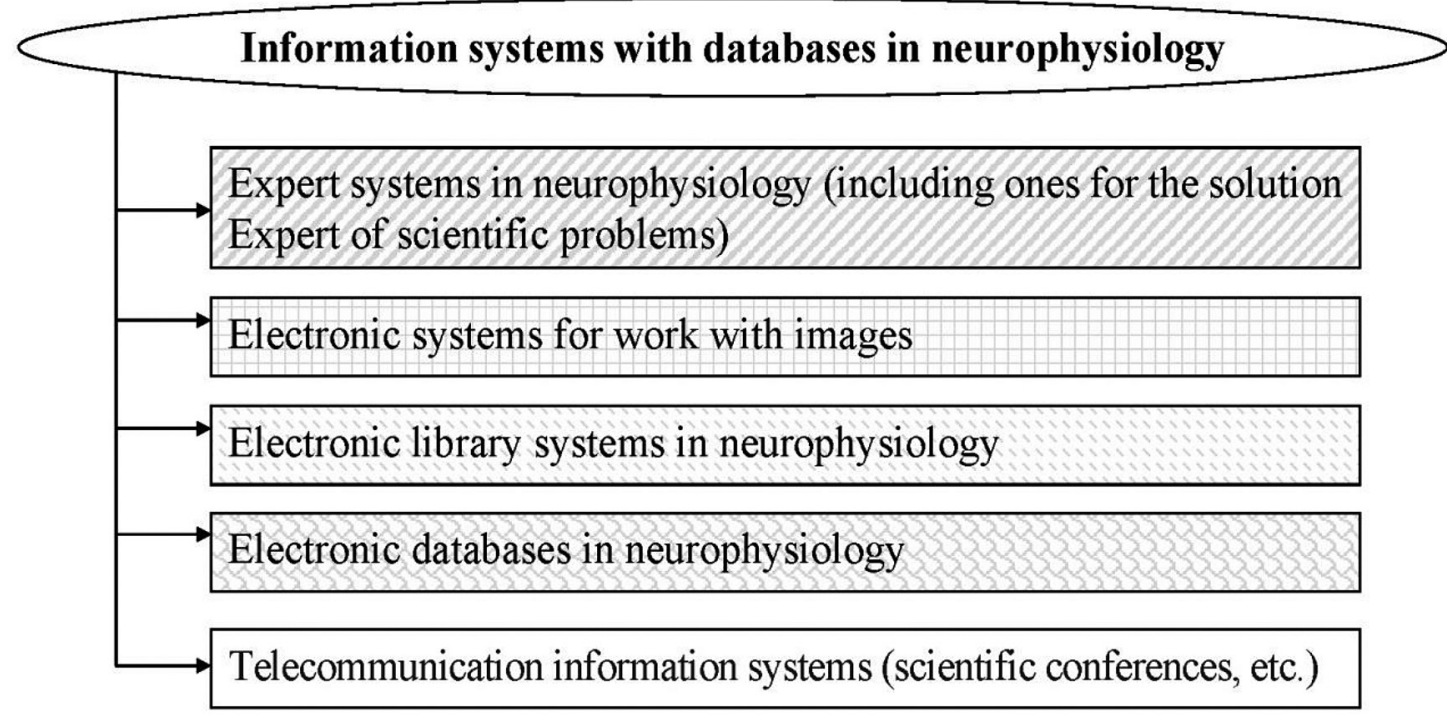

Fig. 4. Information systems with databases in neurophysiology

Comparison of two classifications of contemporary electronic ISs - in medicine and biology. At the current level of development of computer technologies in the medical and biological practice both older ISs according to time of their development, as well as more recent ideas, methods, technologies and developments coexist successfully [2]. Their role and the attention given to their application are determined by practical activity. The reasons of the fast development of ISs with databases in these spheres are the burst-like increase in the amount of input data, which requires the appropriate development of database management systems and ISs.

Medical ISs obtain better funding then biological ones usually, the period of their intensive development 
was during the last 25-27 years. Consequently, medical ISs demonstrate the greater number of varieties in comparison with biological ones [2]. The first biological ISs were developed on 1980-1990-th, but the period of their intensive development was the last 15-16 years. Among the biological ISs, the first ones are those related to industry, medicine (for physiology, brain biology etc.) and business (database with information on biological medicinal products, sales sites and etc.) With regard to such biological ISs, which contain purely academic information, the classification of living organisms, taxonomy data and etc., their examples are not numerous today in comparison with medical ones [2], and their constructing is waiting for their developers still.

Comparing two classifications of modern electronic ISs - in medicine and biology, we can make some conclusions (figs. 2, 3, 4), basing on publications [2-16].

- The medical ISs were characterized by the greatest variety and necessity for the practice.

- Electronic ISs in biology were characterized by the greater proximity to scientific research.

- Examining the numerous works on the development of various ISs in medicine and biology, we saw that developers are focused on the development of: 1) medical ISs of general purpose; 2) electronic library systems; 3) electronic systems for working with documents; 4) expert systems.

- In parallel with these types of systems, the following types of ISs were presented in the publications of world scientific and technical literature: 1) electronic systems for working with images; 2) systems for scientific purposes; 3) electronic teaching systems, and etc.

— «Information systems for telecommunications» occupied the lower position in our scheme. They appeared in our lists and schemes of ISs recently, through few months after the beginning of coronavirus SARS-CoV-2 (2019-nCoV) pandemic. This situation stimulated intensive progress in telecommunicate ISs, their number had increasing dramatically and they appeared in present lists.

Information systems with databases used both by professionals in medicine and biological sciences. Let's observe the examples of ISs with databases used both by professionals in medicine and biology, such as: 1 - areas where the data were used to study the genome, molecular biology and pathophysiology, 2 - related branches of biology: biodiversity, ecology, adaptive biology. Our attention to the designed electronic ISs in these spheres was due to the fact that the author has her own researches in them during long years.

Technical information systems (tISs) in pathophysiology, genome studies, molecular biology and biotechnology. Some time ago, the achievements in these areas of biology were limited by enough low level of individual genes and biological molecules studies, but accelerated development of computer and ISs made it possible to solve such important tasks as, for example, computer scans of thousands samples per day), high-resolution detection systems (thousands of data points for example) and the creation of appropriate electronic ISs. In the United States, the National Center for Biotechnology Information (NCBI) has a collection of databases with genetic sequencing data, decoded protein structures, and other biologic information that are updated constantly, and expanding exponentially.

NcBi published the 146th issue of GenBank, this is a publication on the gene sequences database, which contains an information on 42, 734, 478 gene sequences (February 15, 2005). Before there the results of the full decoding of human genome were published (February, 2001). These events had demonstrated two the most prominent achievements in these areas over the previous 10 years. An outstanding feature was that a large set of biological data has been constantly and completely digitized and recorded into the memory of computer domains of electronic ISs for the first time in the world scientific practice, which became an influential factor of the progress in this field. Today, in addition to human genome, there was continuous work on decoding the genomes of many other living organisms, such as mammals, agricultural, viral and bacterial organisms, which gives humanity fundamental knowledge about the information basis of living systems. Another fundamental discovery of modern biotechnology had become the «highcapacity» scan of genome, in which the integrativity (polymorphism of a separate nucleotide) and the activity (gene expression profiling) for each gene in the same genome can be recorded from the same sample.

This was done by using a technology of DNA milieu platform that can detect tens of thousands of genes, using a small functional system like a post stamp, with data immediately recorded into computer's memory. Information coming from the laboratories working with DNA milieu platforms contained thousands of gene-specific measurements per day. So, the general result of the work with the use of such revolutionary technologies also depended on the level of used 
integrated ISs for the analysis and recording of the data, as well as from the computer system for this gene-specific detection (hybridization).

In the United States, the Food and Drug Administration (FDA) has published guidelines for the development of biotechnological methods, including such as DNA milieu technology platforms, for their use in genetic prognostication and diagnosis of humans; there were indicated that such methods actually initiated a revolution in medicine, which became «more personalized» with their use.

Progress in biochemistry and genome studies faced new challenges, stimulated the development of other branches of science, interdisciplinary research. For example, in [2, 7] it was demonstrated that as a result of the necessity of processing of a huge amounts of experimental data obtained using modern automated experiments in biochemistry, molecular biology, there was a need to create a new set of computer methods and optimization techniques. The peculiarity of such situation was that many of the important problems arising from the researches in computer biochemistry and gene analysis could be formulated in terms of certain combinatorial optimization problems in specially constructed graphs. The authors of the article developed such approaches and offered them to solve new biological problems. The methods used in bioinformatics have been called «the use of mathematical, statistical and computer tools for analyzing of biological data». These were sorting of sequences, phylogenetic trees, predictions of structures, and various modeling methods. Later the recognition was added to this set. Speaking about the main fields of application of computer methods in modern gene and molecular biology, ones told about the study of DNA chains sequences formation, collection of these chains, mapping of genomes, comparison of sequences and analysis of phylogenetic relationships.

The natural extension of IT/CT application in the study of genome and molecular biology phenomena became the field of study and correction of metabolic disorders with IT use $[2,8,11,12]$. The study of metabolic disorders was focused on the research of metabolic mechanisms, the search for effective treatment methods, and improvement of clinical diagnosis during the XX century. The successes that have been achieved in deciphering of gene sequences and associated metabolic data, the success in the development of ISs based on the databases of genome and molecular biology research results, elaboration of database on protein and other biomolecules important in terms of metabolism, allowed ones to transfer some of the developed computer methods to the field of study of metabolism and its disorders. In this article the analytical strategies for bioinformatics were used to process current data both at genome level and at level of metabolism, and then the results were combined to explain certain metabolic disorders. For the analysis of biomedical data in disorders the PathAligner Internet Information System was used, and the results were shown on example of urea cycle disorders.

The «Petri net» model was designed to assess the regulation both at the gene level and at the metabolic level. To explain the regulation of the urea cycle, the transcription factors and signaling pathways were also analyzed. It is known that gene/metabolic defects often cause metabolic blockade and lead to the metabolic disorders. In accordance with the current state of development of methods and concepts of bioinformatics for the analysis of metabolic disorders, it was necessary to understand first the ways of reactions that are effected by encoded gene information (directly or indirectly) and to find out how the modification of the reaction phases and the depletion of metabolites reserves affect the overall response of the system of reactions. For the solution of these problems the methods of biomedical information search and system modeling were used. The PathAligner Webbased system was used to allow users to navigate easily in genetic and metabolic related information. The «Petri net» methodology was used to create a model of biomedical system. For example, in the system of urea cycle modeling, a huge volumes of the data from different databases were used; as a result of which the authors described the metabolic paths and mechanisms, regulatory schemes, and etc. Subsequently, the authors wanted to extend these methods to the study of rheumatoid arthritis and other diseases. The design and analysis of signal network allowed the authors to verify the integrity of the data set. The «base network» constructed by the authors was useful for the next simulation, forecasting and comparison of various cellular systems. The obtained graphical results and the results of dynamic modeling made it possible to understand intuitively the logic of cellular metabolism. Thus, the applied methods of bioinformatics could be considered as non-invasive methods for studying of the functions of genetic and metabolic systems.

The authors of [8] believed that on the basis of their developed methods of bioinformatics, the method 
for integrating of the data and procedures for the modeling of «Petri net» will be following: 1 - to integrate biological and biomedical data; 2 - to create functional structure models; 3 - to predict genetic predisposition to pathologies, disease detection, improved diagnosis, development of new drugs, toxicology; 4 - to use alternative, compensatory metabolic paths instead of damaged, and etc. As a result, the scientists would be able to use such system analysis, for example, to prevent metabolic disorders and comprehensive testing of drugs before their traditional laboratory testing. The authors considered that their main achievement is to integrate various levels of metabolic data using the existing methods of bioinformatics and computer-based methods on the basis of the databases. They believed that the use of IT/ CT can simulate a general scenario of how biomedical systems work, which clinical manifestations can have changes in genes and, consequently, the false changes in the paths of chemical reactions (which follow gene changes); so, what measures are necessary for the prevention of various human pathologies [13, 14]. Thus, in [13], as a result of processing of experimental data from elaborated databases in the corresponding tIS, the authors had found «clusters enriched for genes involved in both cell cycle regulation and cell division, which is biologically reasonable in a cancer orientated dataset». Than they have evaluated their method on both synthetic and gene expression analysis problems.

Some examples of information systems with databases, which combine characteristics of both medical and biological ones. In many recent publications it has been demonstrated that development of ISs with databases in medicine and biology is gradually reducing the distance between biological sciences and medicine $[2,15,16]$. This happened due to number of reasons, but mainly because of the fact that many stored data can be used both in clinical practice and in biological research [2]. Thus, the library system BioMedNet, which contains abstracts of well-known biological and medical journals, is used by physicians, biotechnologists, and biologists as well. The same one can say about the library system Academic Press and Springer, which contain a large number of full-text journals, necessary for biologists and doctors both. To the database with information about proteins and decoded gene sequences apply many professionals — doctors, biologists, specialists from many other linked specialties. In article [15] it was noted that this situation led to the introduction in the United States, primarily at Columbia University, of new courses in the educational process, which combine biological and medical informatics. After the analysis of the state of the problem, the course «Theory and Methods of Biomedical Informatics» was developed there and approved for studying. A similar course was also studied in the Stanford University. The article [16] outlined the latest for these years' methodologies for the development of ISs with databases. These methodologies were based on ontological principles, the developments of ISs with «mixed» information were used widely; and they combined both the databases with gene information and clinical databases. New ontological methods for development of such ISs were needed to facilitate the information search, access to it, and obtain it from the remote Internet resources. One of the areas of application of new ISs developments is biomedicine. This sphere, on expert opinions, would lead soon to new scientific achievements and would accelerate the works on the program «Human Genome Project». The development of such newest ISs in biomedicine were being conducted by European Commission programs, for example, the iNfOGENMED project [2].

Conclusions. In present publication we generalized and analyzed the experience of electronic information systems with databases use. At the beginning we analyzed briefly the development of idea of ISs, examined ISs from numerous scientific and technical publications, suitable for the solutions of different tasks in biomedicine. Then we classified such systems, which traditionally refer to both biological and medical sciences. Further we observed different examples of such information systems, as well as systems that have characteristics both medical and biological in order to facilitate the invention of future more advanced electronic information systems for medicine and biology.

We have demonstrated that there are several basic types of ISs with databases (DBs) for medicine can be subdivided. We have ordered them according to the number of publications devoted to each type; the more publications are dedicated to a particular type of information system (IS), the more left it is. Therefore, in order of decreasing of number of publications, the types of ISs for medicine can be arranged in the following order: medical ISs of general purpose > expert systems $>$ electronic systems with images processing $>$ electronic medical systems for documents processing $>$ systems for scientific purposes $>$ library medical systems $>$ electronic medical training systems $>$ electronic medical databases (DBs). 
By the same principles, the classification of ISs with DBs was done for the biological sciences and neurophysiology, as a branch that provides the results to both medicine and biology. In biology, types of ISs can be arranged in the sequence: scientific ISs with DBs (also with teaching functions) $>$ electronic library systems $>$ electronic biological databases $>$ electronic systems with images processing $>$ expert systems in biology (including ones for scientific problems solution).

Respectively for neurophysiology the part of the items will be identical to the list for ISs designed for medical purposes, other one - with the list for biological ISs. As a result, the general classification sequence for neurophysiology is following: expert systems in neurophysiology (including ones for scientific problems solution) > electronic systems for images processing $>$ electronic library systems in neurophysiology $>$ electronic databases.

Comparing the three above-mentioned versions of contemporary ISs classification - in medicine,

\section{Література.}

1. Перспективи та проблеми використання технологій Big Data в медицині / B. В. Петров, О. П. Мінцер, А. А. Крючин, Є. А. Крючина // Медична інформатика та інженерія. — 2019. — № 3. C. 20-30.

2. Ключко О. М. Інформаційно-комп’ютерні технології в біології та медицині / О. М. Ключко. - К. : НАУ, 2008. - 252 c.

3. Klyuchko O. M. Expert system for biology and medicine / O. M. Klyuchko // Biotechnol. Acta. - 2018. Vol. 11. — № 5. - P. 5-28.

4. Klyuchko O. M. Biotechnical information systems for monitoring of chemicals in environment: biophysical approach / O. M. Klyuchko // Biotechnol. acta. - 2019. — Vol. 12. - № 1. - P. 5-28.

5. Biological databases: using object-oriented system analysis / O. M. Klyuchko, L. P. Buchatsky, O. V. Melezhyk // Biotechnol. Acta. — 2019. — Vol. 12. — № 3. - P. 5-23.

6. Computer recognition of chemical substances based on their electrophysiological characteristics / O. M. Klyuchko, A. Ya. Biletsky // Biotechnol. Acta. — 2019. — Vol. 12. — № 5. - P. 5-28.

7. Web-based expert systems: benefits and challenges / Y. Duan, J. S. Edwards, M. X. Xu // Inf. Manag. — 2005. — Vol. 42. — № 6. - 799811.

8. Towards new information resources for public health From Word Net to Medical Word Net / C. Fellbaum, U. Hahn, B. Smith // J. Biomed. Inform. — 2006. — Vol. 39. — № 3. - P. 321-332. biology, neurophysiology, we would like to make following conclusions: 1 . Medical ISs are characterized by the greatest quantity, diversity and proximity to the practice. 2. Electronic ISs in neurophysiology and biology are characterized by the greater proximity to scientific research. 3 . The main focus of the developers is focused now on the development of: medical ISs of general purposes, electronic library systems, electronic systems for the work with documents, expert systems, telecommunicate systems. 4. Respectively there are fewer publications about the following ISs: electronic systems with images processing, systems for scientific purposes, e-learning systems, and etc. 5. Telecommunicate ISs appeared in our lists and schemes of ISs recently, through few months since the beginning of coronavirus SARS-CoV-2 (2019$\mathrm{nCoV}$ ) pandemic. This situation stimulated intensive progress in telecommunicate ISs, their number had increasing dramatically and can be added to present lists too. Other ISs types were represented less than above mentioned ones.

9. Network oriented radiological and medical archive / M. Ferraris, P. Frixione, S. Squarcia // Comp. Physics Commun. - 2001. - V. 140. - P. 226-232.

10. Information technology challenges of biodiversity and ecosystems informatics / J. L. Schnase, J. Cushing, M. Frame // Information systems. - 2003. - V. 28. № 4. - P. 339-345.

11. Essen van D. C. Windows on the brain: the emerging role of atlases and databases in neuroscience / D. C. Essen van // Curr. Opin. Neurobiol. — 2002. — V. 12. — № 5. - P. 574-579.

12. An ontological approach to modeling tasks and goals / J. Fox, A. Alabassi, V. Patkar, T. Rose, E. Black // Comp. Biol. Med. - 2006. — V. 36. — P. 837-856.

13. A nonparametric variable clustering model / K. Palla, Z. Ghahramani, D. A. Knowles // Advances in Neural Information Processing Systems. — 2012. - P. 2987-2995.

14. Combining full text and bibliometric information in mapping scientific disciplines / P. Glenisson, W. Glänzel, F. Janssens, B. D. Moor // Inf. Proc. Manag. — 2005. — Vol. 41. - № 6. - P. 1548-1572.

15. Bridging the gap between biological and clinical informatics in a graduate training program / S. B. Johnson, R. Friedman // J. Biomed. Inform. — 2007/ — № 40 (1). — P. 59-66.

16. Ontofusion: Ontology_based integration of genomic and clinical databases / D. Pérez-Rey, V. Maojo, M. García-Remesal et al. // Comp. Biol. Med. — 2006. — Vol. 36. — № 78. — P. 712-730.

17. Ключко О. М. Спосіб застосування біотехнічної системи моніторингу для обліку біоіндикаторів 
з біосенсором та підсистемою оптичної реєстрації / O. М. Ключко. - Патент UA 129987 U, G01N33/00, C12Q 1/02, С12N 15/00. Опубл: 26.11.2018, Бюл. 22. $-11 \mathrm{c}$.

18. Спосіб застосування системи моніторингу з біосенсором та базами даних / О. М. Ключко, А. Я. Білецький, Г. В. Лізунов, О.В.П’янкова. - Патент UA 135574 U; C12Q1/02, G01N33/00, G01N33/50, G016F 11/20. Опубл: 10.07.2019, Бюл. 13. - 10 с.

\section{References.}

1. Petrov, V. V., Mintser, O. P., Kryuchin, A. A., Kryuchina, Ye. A. (2019). Big Data in medicine: promise and challenges. Medical informatics and engineering, 3, 20-30. doi: https://doi.org/10.11603/mie.19961960.2019.3.10429.

2. Klyuchko, O. M. (2008). Information and computer technologies in biology and medicine. Kyiv: NAU, 252. [In Ukrainian].

3. Klyuchko, O. M. (2018). Expert system for biology and medicine. Biotechnol. acta, 11 (5), 5-28. https://doi. org/10.15407/biotech11.06.005.

4. Klyuchko, O. M. (2019). Biotechnical information systems for monitoring of chemicals in environment: biophysical approach. Biotechnol. acta, 12 (1), 5-28. https://doi.org/10.15407/biotech.

5. Klyuchko, O. M., Buchatsky, L. P., Melezhyk, O. V. (2019). Biological databases: using object-oriented system analysis. Biotechnol. acta, 12 (3), 5-23. https:// doi.org/10.15407/biotech12.03.005.

6. Klyuchko, O. M., Biletsky, A. Ya. (2019). Computer recognition of chemical substances based on their electrophysiological characteristics. Biotechnol. acta, 12 (5), 5-28. https://doi.org/10.15407/biotech12.05.005.

7. Duan, Y., Edwards, J. S., Xu, M. X. (2005). Web-based expert systems: benefits and challenges. Inf. Manag., 42 (6), 799811. https:// doi.org/10.1016/j.im.2004. 08.005.

8. Fellbaum, C., Hahn, U., Smith, B. (2006). Towards new information resources for public health From Word Net to Medical Word Net. J. Biomed. Inform., 39 (3), 321-32. doi: 10.1016/j.jbi.2005.09.004.
9. Ferraris, M., Frixione, P., Squarcia, S. (2001). Network oriented radiological and medical archive. Comp. Physics Commun., 140, 226-32. https://doi.org/10.1016/ S0010-4655(01)00273-9.

10. Schnase, J. L., Cushing, J., Frame, M. (2003). Information technology challenges of biodiversity and ecosystems informatics. Information systems, 28 (4), 339-45.

11. Essen van, D. C. (2002). Windows on the brain: the emerging role of atlases and databases in neuroscience. Curr. Opin. Neurobiol. 12 (5), 574-9. https://doi. org/10.1016/ S0959-4388(02)00361-6.

12. Fox, J., Alabassi, A., Patkar, V., Rose, T., Black, E. (2006). An ontological approach to modeling tasks and goals. Comp. Biol. Med., 36, 837-56. https://doi. org/10.1016/j. compbiomed.2005.04.011.

13. Palla, K., Ghahramani, Z., Knowles, D. A. (2012). A nonparametric variable clustering model. Advances in Neural Information Processing Systems, 2987-995.

14. Glenisson, P., Glänzel, W., Janssens, F., Moor, B. D. (2005). Combining full text and bibliometric information in mapping scientific disciplines. Inf. Proc. Manag., 41 (6), 1548-72. https://doi.org/10.1016/j.ipm.2005.03.021.

15. Johnson, S. B., Friedman, R. (2007). Bridging the gap between biological and clinical informatics in a graduate training program. J. Biomed. Inform., 40 (1), 59-66. doi: 10.1016/j.jbi.2006.02.011.

16. Pérez-Rey, D., Maojo, V., García-Remesal, M. et al. (2006). Ontofusion: Ontology-based integration of genomic and clinical databases. Comp. Biol. Med. 36 (78), 712-30. doi: 10.1016/j.compbiomed.2005.02.004.

17. Klyuchko, O. M. (2018). Method of application of biotechnical monitoring system for bioindicators' accounting with biosensor and sub-system for optical registration. - Patent UA 129987 U, G01N33/00, C12Q 1/02, C12N 15/00. Issued: 26.11.2018, Bull. 22, 11. [In Ukrainian].

18. Klyuchko, O. M., Biletsky, A. Ya., Lizunov, G. V., Piankova, O. V. Method of application of monitoring system with biosensor and databases. Patent UA 135574 U; C12Q 1/02, G01N33/00, G01N33/50, G016F 11/20. Issued: 10.07.2019, Bull. 13, 10. [In Ukrainian]. 